Please do not remove this page

RMIT

UNIVERSITY

\title{
Movies and holidays: The empirical relationship between movies and tourism
}

Mitchell, Heather; Stewart, Mark

https://researchrepository.rmit.edu.au/esploro/outputs/9921858016901341/filesAndLinks?institution=61RMIT_INST\&index=null

Mitchell, H., \& Stewart, M. (2012). Movies and holidays: The empirical relationship between movies and tourism. Applied Economics Letters, 19(15), 1437-1440. https://doi.org/10.1080/13504851.2011.631888

Document Version: Submitted Version

Published Version: https://doi.org/10.1080/13504851.2011.631888

Repository homepage: https://researchrepository.rmit.edu.au

(C) 2012 Taylor and Francis Group, LLC

Downloaded On 2023/04/26 09:33:05 +1000

Please do not remove this page 
Thank you for downloading this document from the RMIT Research Repository.

The RMIT Research Repository is an open access database showcasing the research outputs of RMIT University researchers.

RMIT Research Repository: http://researchbank.rmit.edu.au/

\section{Citation:}

Mitchell, H and Stewart, M 2012, 'Movies and holidays: The empirical relationship between movies and tourism', Applied Economics Letters, vol. 19, no. 15, pp. 1437-1440.

See this record in the RMIT Research Repository at:

http://researchbank.rmit.edu.au/view/rmit:16319

Version: Submitted Version

Copyright Statement: (c) 2012 Taylor and Francis Group, LLC

Link to Published Version:

http://dx.doi.org/10.1080/13504851.2011.631888

\section{PLEASE DO NOT REMOVE THIS PAGE}




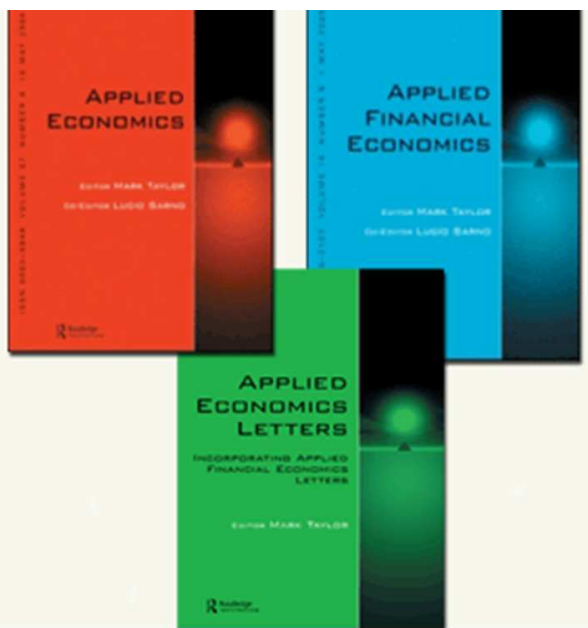

Movies and Holidays

\begin{tabular}{|r|l|}
\hline Journal: & Applied Economics \\
\hline Manuscript ID: & Draft \\
\hline Journal Selection: & $\begin{array}{l}\text { Applied Economics Letters incorporating Applied Financial Economics } \\
\text { Letters }\end{array}$ \\
\hline Date Submitted by the Author: & n/a \\
\hline Complete List of Authors: & $\begin{array}{l}\text { Mitchell, Heather; RMIT University, School of Economics, Finance and } \\
\text { Marketing } \\
\text { Stewart, Mark; RMIT, Economics \& Finance }\end{array}$ \\
\hline JEL Code: & $\begin{array}{l}\text { C22 - Time-Series Models < C2 - Econometric Methods: Single Equation } \\
\text { Models < C - Mathematical and Quantitative Methods, L82 - Entertainment; } \\
\text { Services < L - Industrial Organization, L83 - L8 - Industry Studies: } \\
\text { Sports |Gambling|Recreation|Tourism < L8 - Industry Studies: Services < L } \\
\text { - Industrial Organization }\end{array}$ \\
\hline Keywords: & \begin{tabular}{l} 
Time Series Models, Films, Entertainment, Tourism \\
\hline
\end{tabular} \\
\hline
\end{tabular}




\title{
Movies and Holidays The empirical relationship between movies and tourism
}

\author{
Heather Mitchell \& Mark Stewart \\ September 2011
}

\begin{abstract}
Governments around the world believe tourism will increase if locations within their nations are featured in films. Money and other inducements are often offered to movie makers to encourage them to shoot within a particular constituency. This paper finds a positive and statistically significant relationship between successful films and tourism.
\end{abstract}

Mark F. Stewart (corresponding author)

School of Economics, Finance and Marketing, RMIT University

City Campus.

239 Bourke Street,

Melbourne Victoria 3000.

AUSTRALIA

Telephone +6139925 5879

Facsimile +6139925 5986

Email:mark.stewart@rmit.edu.au

Heather Mitchell

School of Economics, Finance and Marketing, RMIT University

Telephone +61399255876

Email: heather.mitchell@rmit.edu.au 


\section{Movies and Holidays The empirical relationship between movies and tourism}

\section{Introduction}

New Zealanders took pride and gained a heightened national profile with the filming of the Lord of the Rings trilogy in their country. When they were planning to film the follow-up movie The Hobbit, Warner Brothers pressured the New Zealand government to change their employment act and provide a package of around $\$ 25$ million worth of tax breaks to bring the filming to the country (Clark, 2010). This is just one example of how a government's inducements can convince movie makers to showcase their particular nation. This investment is often justified as leading to increased tourism. This paper endeavours to answer the question: Are these inducements worthwhile?

Although studies have documented increases in tourism to locations featured in movies and television (e.g., Riley and Doren 1993; Riley et al., 1998; Dore and Crouch, 2003; and Kim et al., 2009), the question of whether this represents an increase in overall tourism, or merely a diversion from other destinations within the same country, has not been adequately addressed. To investigate this, we examined changes in overseas tourist numbers to Australia following the Mad Max and Crocodile Dundee franchises, and New Zealand following the Lord of the Rings trilogy. We also consider the available tourist-related data on Kazakhstan before and after the Borat movie.

\section{The Data}

We chose Australia and New Zealand because they are both distant from overseas locations and require a deliberate decision to visit. These sites also have reliable monthly data over an extended period, which is assisted by having no land borders. Figure 1 shows the logged values of tourists in 
these two countries ${ }^{1}$. The US release date of the first of each movie series has also been shown on the Figure.

\section{Figure 1: Tourist Arrivals}

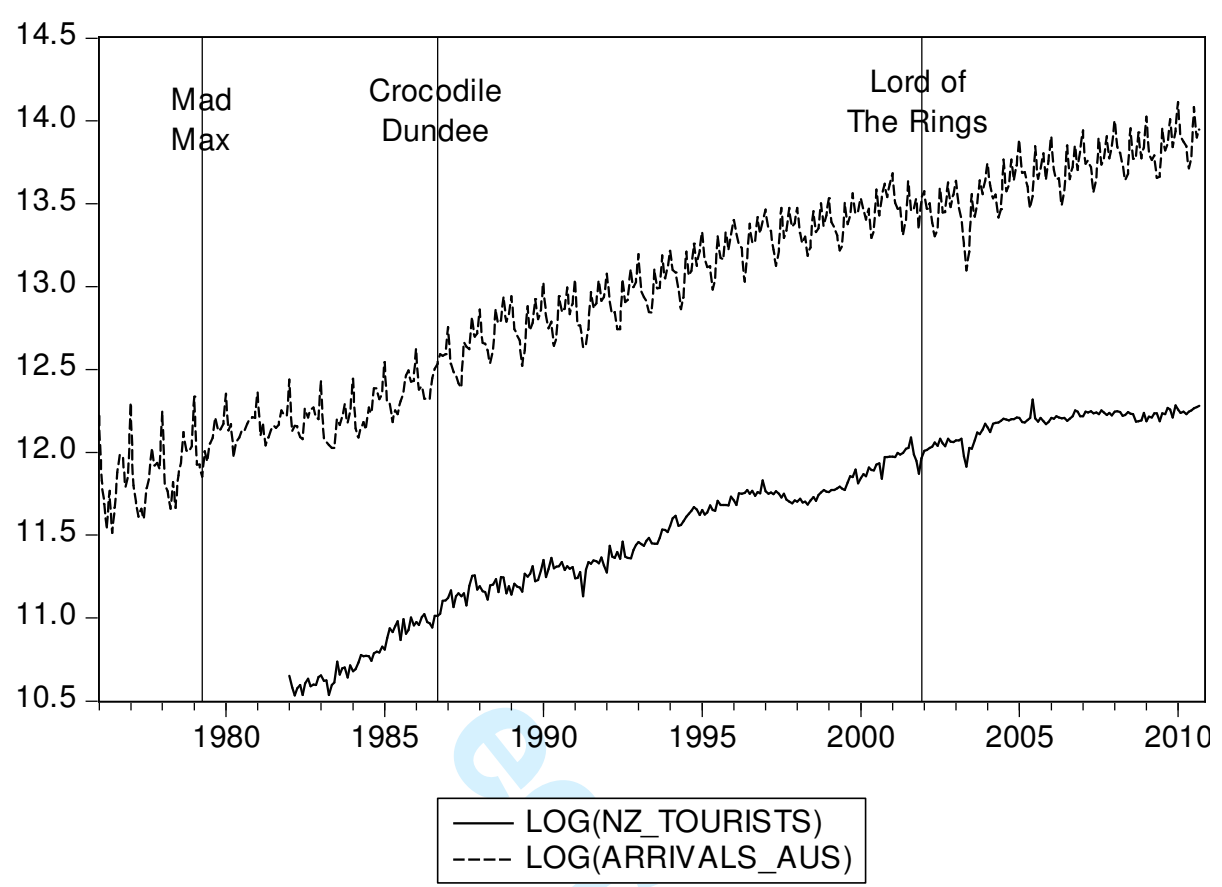

Both series show a general upward trend, with strong seasonal effects evident in the Australian series. The dramatic drop for Australia in 2003 corresponds to the Severe Acute Respiratory Syndrome (SARS) epidemic. We fit a linear trend $(T r)$ to the logged data to estimate the growth rate with the trend set to zero at the release date of the first movie in a series. Monthly seasonal dummy variables are included where required, as well as dummy variables to measure the impact of SARS. Where sufficient data is available, the estimation periods begin five years before the release of the first movie in the franchise and end five years after the release of each movie in the series ${ }^{2}$. As the third Crocodile Dundee movie was screened 13 years after the second, it is analyzed separately. An additive dummy variable $(D A)$ starting at the film's US release date is included to detect an overall increase, and a multiplicative dummy using the time trend is used to measure any change in growth rates.

\footnotetext{
${ }^{1}$ NZ_TOURISTS and ARRIVALS_AUS are defined in Table 1.

${ }^{2}$ The five year period is chosen as Riley et al (1998) find that increases to featured locations generally decline after this time. 


$$
\log \left(\text { Tour }_{t}\right)=\alpha_{0}+\beta_{1} \operatorname{Tr}+\beta_{2} D A_{t}+\beta_{3} \operatorname{TrDA} A_{t}+\alpha_{2} D_{2}+\cdots+\alpha_{12} D_{12}+\beta_{4} S_{1}+\cdots+\beta_{6} S_{3}
$$

where Tour is the measure of tourist numbers given in Table $1, D_{2} \ldots D_{12}$ are monthly seasonal dummy variables and $S_{1} \ldots S_{3}$ model the effect of SARS. Newey-West HAC adjusted t-statistics are used in all regressions and some ARMA terms are used when required ${ }^{3}$. The seasonal dummy variables were significant for Australia and Kazakhstan, but not for New Zealand. The SARS dummies show a significant negative effect for both Australia and New Zealand. ${ }^{4}$

In an attempt to provide a control for general changes in tourism to the area, we estimate the models using both New Zealand and Australian data where data is available. All series were collected through the Thomson Reuters DataStream and found to be trend stationary using the Kwiatkowski-Phillips-Schmidt-Shin (KPSS) test.

\section{Empirical Results}

Table 2 shows that each of the Mad Max franchise films were associated with a significant increase in tourism after the release of the first movie, but there is a decrease in the growth rate that negates this after a year. As the plot was not specifically Australian, and the scenery not appealing, any increase is surprising.

The first two Crocodile Dundee movies coincide with an increase in Australian tourism but, unlike the Mad Max movies, there is no decrease in the growth rate. Over the same period, there is also an increase in tourism to New Zealand, but not as large as for Australia. This is followed by a decrease in growth that negates the increase after 10 months. This could be due to a contagion effect, with some tourists who travelled to Australia deciding to visit New Zealand as well. The third Crocodile Dundee movie corresponds to a decrease in tourism to Australia. This could be because the movie was not successful, or that there was little Australian footage, or because the

\footnotetext{
${ }^{3} \mathrm{HAC}$ is Hetroskedastic Autocorrelation Consistent and ARMA is Auto Regressive Moving Average. Details of the ARMA terms used in our models are available from the authors on request.

${ }^{4}$ The results are not reported but are available from the authors on request.

Editorial Office, Dept of Economics, Warwick University, Coventry CV4 7AL, UK
} 
Lord of the Rings movies were released during the estimation period and tourists were diverted to New Zealand. Over the same period, tourists to New Zealand show a marginally significant increase.

When we examined the impact of the Lord of the Rings trilogy on New Zealand tourism, we find no significant effects for the first movie, but after the second and third there is an increase in tourist numbers. This is accompanied by a decrease in growth that would negate the increase after two years. Over the same period, there is a drop in the number of tourists to Australia, but a small increase in the growth rate. This suggests there may be a diversionary effect, which dissipates slowly.

As a change of pace we look at the influence of Borat's release in 2006 on Kazakhstan tourism. Unfortunately, data is limited. Quarterly data on foreign direct investment in hotels and restaurants from the National Bank of Kazakhstan shows an increased mean value from USD \$3.0 million before the movie to USD\$11.7 million after it $^{5}$. A t-test for equality of the two means rejects the null at the $5 \%$ level $(\mathrm{p}$-value $=0.030)$. A similar model to that for tourist numbers was estimated using data on employment in hotels and restaurants in Kazakhstan is presented in Table $2^{6}$. The employment figures show a significant increase in employment shortly after the release of the movie. If these effects are due to the movie, Kazakhstan has done very well. They made no financial contribution of any kind to the film and the "Kazakhstan" scenes were shot in Romania" This is interesting given that the Kazakhstan president, Nursultan Nazarbayev, complained about the movie portraying his country in a bad light ${ }^{8}$.

5 The data started in the first quarter of 2001.

6 No comparable data is available for similar countries.

7 This effect is not uncommon (see Busby and Klug, 2001), and is attributed to playful or 'post-tourists' (Williams, 1998, p. 181) rather than ignorance of the movie's true location.

${ }^{8}$ See Daily Mail, 2006. 


\section{Conclusion}

Using data on tourist numbers to Australia and New Zealand, and hospitality employment in Kazakhstan, we find evidence of an increase in tourism after the release of a movie. However, this increase is not generally sustained for more than two years. It does not seem to matter if the movie is specifically set in that location or a fictional one, such as the Lord of the Rings' Middle Earth. This effect may be present even if the movie claims to be set in a particular location, but is actually filmed elsewhere. There is also some evidence of both contagion and diversion effects.

As our study shows, the third Crocodile Dundee movie, which was not a box-office success, had no positive effect on tourism. Government support for movies, then, must be considered a gamble. Whether the inducements offered by governments to entice movie makers to shoot within their countries are worthwhile requires a full cost benefit study that would compare what the governments invest with the dollar value of the extra tourism. 


\section{Page 7 of 9}

Submitted Manuscript

\section{Table 1: Data sources}

\section{\begin{tabular}{|l|l}
\hline Country & Series \\
\hline
\end{tabular}}

\begin{tabular}{|l|l}
\hline Australia & Visitor Arrivals - purpose of visit holiday
\end{tabular}

Australia

Visitor Arrivals - purpose of visit holiday

Kazakhstan

No. of Employees - hotels and restaurants

\begin{tabular}{l|l}
\hline Source & Time period
\end{tabular}

Australian Bureau of Statistics

Australian Bureau of Statistics

Agency of Kazakhstan on Statistics

Jan 1976 to Nov 2010

Jan 1976 to Nov 2010

Movies

New Zealand

Short term visitor arrivals

Statistics New Zealand

Mad 1979, 1981, 1985

Crocodile Dundee, 1986, 1988, 2001

April 2000 to Dec $2009 \quad$ Borat 2006

10

11
12

13

13
14

15

16

17

18

19

20

21

22

23

24

25

26

27

28

29

30

31

32

33

34

35

36

37

38

39

40

41

42

43

44

45 
Table 2: Regression results ${ }^{9}$

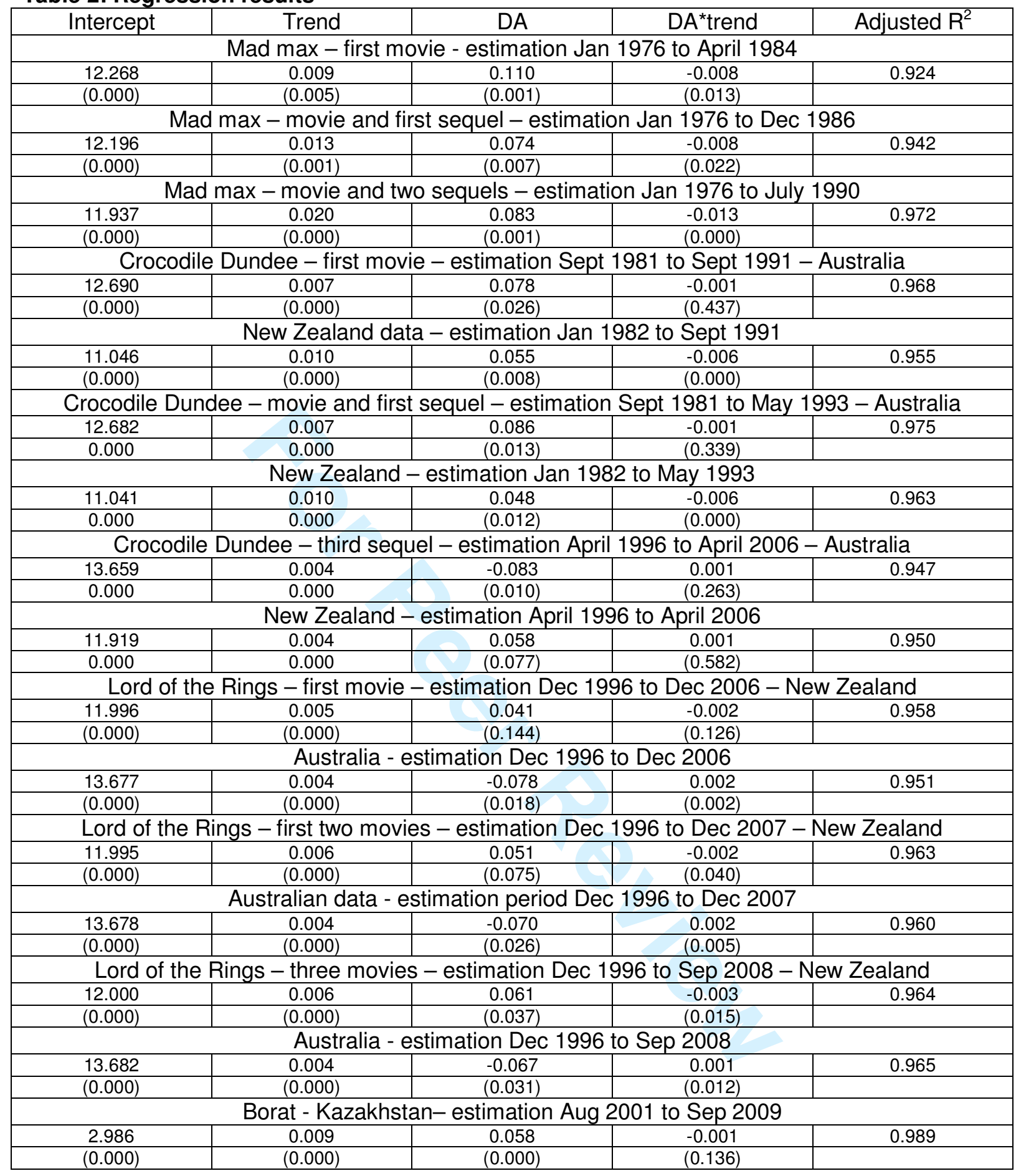

${ }^{9} \mathrm{p}$-values in parenthesis.

Editorial Office, Dept of Economics, Warwick University, Coventry CV4 7AL, UK 


\section{References}

Busby G. and Klug J. (2001) Movie induced tourism: the challenge of measurement and other issues, Journal of Vacation Marketing, 7, 318-332.

Clark, A. (2010) New Zealand changes labour laws to save filming of the Hobbit movies, The Observer, 31 October, 2010.

Daily Mail. (2006) Bush to hold talks on Ali G creator after diplomatic row, Daily Mail, 12 September, http://www.dailymail.co.uk/news/article-404852/Bush-hold-talks-Ali-Gcreator-diplomatic-row.html (accessed September 2011).

Dore L. and Crouch G. I. (2003) Promoting destinations: an exploratory study of publicity programmes used by national tourist organizations, Journal of Vacation Marketing, 9, 137-151.

Kim, H. J., Chen, M. H., and Su, H. J. (2009) The impact of Korean TV dramas on Taiwanese tourism demand for Korea, Tourism Economics, 15, 867-873.

Riley, R., Baker, D., and Van Doren, C. S. (1998) Movie induced tourism, Annals of Tourism Research, 25, 919-235.

Riley, R.W. and Van Doren, C. S. (1992) Movies as tourism promotion: a 'pull' factor in a 'push' location, Tourism Management, September, 267-275.

Williams, S. (1998) Tourism Geography, Routledge, London. 